Diante da repetição pulsional, nenhum dispositivo de poder tem a garantia de que será bem sucedido. 0 poder, em última instância, tem relação com o ser e triunfa sobre todas as produções de saber e do prazer. Todo poder sobre o sexo, todo desejo de liberação sexual, toda colocação do sexo em discurso está fadado, pelo seu fracasso, a recomeçar novamente.

É nesse ponto que o pensamento sobre uma segunda clínica de Lacan tem pertinência. Uma clínica que se desloca do axioma de "o inconsciente estruturado como uma linguagem" para aquele em que "a relação sexual não existe". Que mudanças se operam a partir daí? Como pode a psicanálise operar o seu discurso libertário ou, ao contrário, seu discurso de responsabilidade simbólica, se hoje tratamos com a inconsistência do grande $\mathrm{Ou}$ tro que ela própria ajudou a desvendar?

A questão pode se apresentar de outra forma: seria possível conduzir os indivíduos modernos submetidos ao ideal de ciência que os lança à deriva no campo do saber, rumo ao ideal de análise? Ou ainda, a psicanálise pode constituir uma clínica que leve a cabo a potência última de sua descoberta, ou seja, o poder do fracasso de todas as produções de saber e dispositivos de prazer que se arrojam na tentativa de garantir o gozo?

Para terminar, o que podemos dizer é que o livro não somente lança essas e outras tantas questões como também assume o risco, político, de tentar respondê-las.

Recebido em 21/ 8/ 2002.

Aprovado em 9/9/2002.

André Martello

Rua Eduardo Santos 161/ 201

20251-460 SantaTereza

Rio de Janeiro RJ

Tel.: 2507-5464 / 9197-5567

martello@uninet.com.br

\section{POR UMA PSICANÁLISE POIÉTICA}

\section{$A$ invenção da vida: arte e}

psicanálise. A. Slavutzky, E. L. A. de

Sousa, E. Tessler (orgs.), Porto Alegre,

Artes e Ofícios, 2001, 191 p.

\section{André M artins}

Psicanalista. Doutor em Filosofia pela Université de Nice, França; doutor em teoria psicanalítica pela UFRJ; professor adjunto dos cursos de Pós-graduação em Medicina, Saúde Coletiva e Filosofia da UFRJ.

"Arte e psicanálise", diz o subtítulo de A invenção da vida. No entanto, muito mais do que correlacionar arte e psicanálise, este livro organizado por dois psicanalistas e uma artista plástica gaúchos, reunindo artigos de psicanalistas e artistas de Porto Alegre, São Paulo e Paris, se propõe a pensar a própria psicanálise como atividade criativa - como elemento capaz de contribuir ativamente para uma modificação criativa nos afetos e na dinâmica de vida do paciente. Ou mesmo de constituir-se tal como uma arte, não só em seu domínio clínico mas também teórico e cultural.

Stéphane Huchet delimita esta diferença: "houve um tempo, no país de Lacan (là, quand...), em que a psicanálise representou um espectro ideológico incontornável na paisagem crítica da arte e da literatura. Ideológico, isto é, de captura e de fechamento a priori da realidade por tal modelo teórico." Exercício dogmático de submissão da arte à suposta Verdade epistemológica da psicanálise, constituindo assim "um freudismo fundamentalista", segundo o qual "a teoria psicanalítica (...) era concebida como o único modelo teórico capaz de dar conta da realidade, que não poderia ter sentido senão por meio da grade sobretudo freudiana", relata Huchet. A arte moder- 
na e suas vanguardas consistiriam em "tentativas de superar o interditado da Lei, sem alcançar sua meta". Face a esse quadro, Huchet se pergunta se a psicanálise pode existir "sem Hegel, isto é, sem querer trazer as sombras do espírito à luz da consciência e do conceito".

A resposta do livro é positiva, e seus artigos tentam, portanto, não mais psicanalisar a arte mas, ao contrário, conceber a psicanálise sob o ponto de vista da arte. Algo como a proposta nietzschiana, no prefácio a 0 nascimento da tragédia, de se ver o conhecimento sob a ótica do artista - assim como a arte sob a ótica da vida. "A vida não existe, ela tem de ser inventada", afirmam os organizadoresna "Apresentação" . Criação de si, foucaultianamente como a uma obra de arte, em uma tessitura do texto e da clínica. Se "as ficções que podemos construir pela experiência da fala e da escuta mostram 0 sempre inacabado do que acreditamos ser", conceber a psicanálise como uma "poianálise", tal como sugere o poeta e professor da Sorbonne René Passeron, objetiva assumir afirmativamente este inacabamento, e por conseguinte a tarefa contínua - e neste sentido comum à arte $\mathrm{e}$ à psicanálise assim entendida - da "experiência do criar", que surpreende "a quietude repetitiva do mundo". "O faber está sempre em nós", escreve Passeron; "o sapiens é seu luxo, quando, fatigado, ele se senta, enfim, em seu recolhimento noturno. Estará sonhando? Se deita ele sobre um divã? ( ...) Ele entra na esfera da poiética como noesis pieseôs."

O livro ganha em atualidade e pertinência quando percebemos que, como se sabe, não é essa a postura tradicional da psicanálise. Embora Freud tenha se utilizado, desde os escritos inaugurais da psicanálise, de imagens literárias para apoiar as teses psicanalíticas, "uma pro- funda ambigüidade rege esta relação" de Freud com a arte, oscilando "entre o rancor acusatório e a redescoberta maraviIhada de um parentesco negado ou desconhecido", observa Noemi Moritz Kon. Esta aparentemente paradoxal relação com a arte, detecta Kon, guarda uma coerência interna na obra de Freud: quando "toma por interlocutores privilegiados alguns artistas específicos e suas obras" e, somente então, Freud assume "uma postura de total admiração" para com a poesia; já "quando Freud constrói uma teoria geral do fazer artístico", "o artista é tratado como um rival arrivista vulgar, que acoberta ou trai a verdade, em causa própria", para fins de "sucesso ou popularidade".

Em Escritos criati vos e devanéo (1907), no qual Freud "tece sua teoria geral sobre 0 fazer artístico", o artista é interpretado como sendo impulsionado por seus "desejos insatisfeitos", buscando, através da criação artística, "uma correção da realidade insatisfatória". Em 0 estranho (1919), o artista e sua obra são vistos como tendo "uma função insidiosa e mistificadora, papel contrário ao do psicanalista", que trabalharia sob as "forças das luzes" da razão, a fim de "al cançar a verdade".

Em Um estudo autobiográfico (1925), Freud compara o trabalho artístico "à fabricação do sintoma neurótico". Tomar a obra de arte "como uma produção fantasmática" a serviço do "encobrimento de um conflito anterior", este sim encarado como "original", seria uma forma de evitar que a própria atividade psicanalítica seja vista como uma criação artística, analisa Kon tendo por base o trabalho de Monique Schneider sobre a resistência de Freud ao imaginário.

Em sintonia com o projeto do livro, Kon propõe que nos deixemos impregnar "pela potência estética, acatando este poder implícito à atividade psicanalíti- 
ca, abandonando uma postura restritiva contida na visão freudiana da obra de arte". Acumpliciar-se da experiência artística propiciaria maior compreensão sobre a própria psicanálise - como capaz de constituir-se em uma criação originária, e não como um sintoma a ser interpretado na busca de se detectar suas supostas causas lineares, seus supostos conflitos originais. "Para tanto, é necessário renunciar a uma vertente tão insistentemente utilizada em nosso meio", alerta, "que é a de constituir uma psicopatobiografia", que teria como "pretensão, compreender a obra de arte como sintoma da vida do artista". "Da postura que adotarmos relativamente a essa questão surgirão práticas psicanalíticas muitíssimo diversas", constata. Tratar-se-ia do abandono de uma prática "arqueológica", em prol de um fazer "criador", em que "os sentidos e significados são gerados no próprio encontro psicanalítico, numa gênese sempre reiterada de realidades singulares". Abrir mão de "hipóteses filogenéticas" que somente fizeram "atrasar o marco traumático, ancorandoo numa história (ou pré-história) material - mesmo que mítica".

Esta "necessidade de um apoio numa realidade factual" acabaria por ter simplesmente a função de apaziguar as angústias do próprio psicanalista face às do paciente. Pela "negação da liberdade criadora", o psicanalista pode então "seguir tranqüilo em seu trabalho, imaginandose como aquele que", protegido por seu lugar, "desvenda, abre realidades, histórias, sintomas, sonhos e obras". Ao invés de tradutor de "sentidos dissimulados", o fazer psicanalítico torna-se "fundante" de "múltiplos sentidos", de "realidades singularesinéditas", como um "gesto criador presente". É à clínica que se dirige esta proposta de mudança do olhar, fina- liza Kon, pois é "em parceria e cumplicidade com aqueles que vêm ao nosso encontro" que a psicanálise se efetiva como um fazer criativo.

Em um livro cuja proposta consiste em pensar uma psicanálise afirmadora do presente relacional do setting como espaço para a gênese imanente de subjetividades criativas, não poderia faltar menção ao psicanalista que fizera de sua clínica e de sua teoria uma potente compreensão da psicanálise como atividade criadora, D. W. Winnicott. Face à insuficiência da abordagem psicanalítica clássica da experiência artística - que "procurou reduzir sonho e obra de arte a um mesmo componente interno, a fantasia inconsciente", entendendo a obra como "expressão fantasiosa dos desejos de seu criador", de modo que a relação desta com o receptor seria a de "reatualização das fantasias pessoais próprias a cada espectador" - , João Frayze-Pereira encontra em Winnicott material conceitual e clínico para compreender "mais profundamente a natureza psicológica da relação" entre a arte e o espectador.

A noção de "zona intermediária da experiência", formulada por Winnicott, permite a compreensão de que a obra cria um espaço imaginário - " transicional" - "entre o eu do espectador e o outro", "que não é a mera adição da realidade interna e da realidade externa, mas possui consistência própria", explica, citando Rogério Luz. "A obra abre um espaço de experiência que articula o sujeito psicológico e o mundo", tal como ocorre na relação do bebê com a mãe nos primeiros meses de vida, assim como durante toda a infância e mesmo durante a vida adulta, no sentido de que, justamente, a saúde psíquica consiste em uma apropriação singular e criativa da realidade partilhada. 